our cancer research programme. In 1951 the Royal Society gave the Laboratory a grant of $£ 3,500$, which was particularly welcome because, being unrestricted, it could be used at the Trustees' discretion.

During the past decade, the biological interests of the Laboratory have shifted more and more from purely morphogenetic to physiological problems; in consequence the lack of an adequate biochemical section became a severe handicap. The Wellcome Trust, however, came to our rescue with a magnificent grant of $£ 60,000$ with which to build and equip a new wing (Fig. 1). This oxtension not only provided modern biochemical laboratories but also suitable accommodation for the Siemens electronmicroscope, presented to us in 1954 by the Rockefeller Foundation, and for the new X-ray set supplied for our use by the British Empire Cancer Campaign from money collected by members of the Inner Wheel. The new wing was opened by Sir Honry Dale in 1959, and has extended the scope of our research to a remarkable degree. Recently, in honour of our fiftieth anniversary, the Fleming Memorial Trust has made a splendid gift of $£ 10,000$ to buy equipment for fundamental research on cell physiology.

Legally, the Strangeways Research Laboratory remains what it was in its research hospital days, namely, an independent charitable institution controlled by a board of Trustees. The present Trustees are: Sir Rudolph Peters (chairman), Dr. Malcolm Donaldson, Lord Adrian, Sir Henry Dale and Dr. P. B. Medawar. At the present time it usually accommodates 25-30 research workers. The staff includes a varied assortmont of biologists, two pathologists, four biochemists, three physicists and a biophysicist; in addition, there are always a number of guest workers from other institutions in the United Kingdom and abroad, and usually two research students working for the Cambridge Ph.D. degree.

An unusual feature of the organization is the fact that no member of the research or technical staff is paid out of the Laboratory's own funds. Three members of the research staff hold Sir Halley Stewart fellowships which were generously established by the Sir Halley Stewart Trustees to enable us to provide some permanent key appointments. Other members of the Laboratory belong to the Medical Rosearch
Council's external staff, others are supported by the British Empire Cancer Campaign, and I myself hold a Foulerton Research Fellowship under the Royal Society. No account of the Laboratory's history would be complete without a tribute to the loval service of the technical staff, some of whom have been with us for 25-50 years. The wide variety of scientific disciplines represented by the research staff is a great advantage, because it enables us to approach a given problem from several different directions; in addition, we collaborate with a number of specialists in other departments. The methods in genoral use include animal experiments, organ culture, cell culture, microchemical and cytochemical procedures, and electronmicroscopy.

Among the purely biological problems now being investigated are: the action of vitamins and hormones on the structure and metabolism of tissues and cells in vivo and in vitro, and isolated cell organelles; the properties of the cell surface; intercellular relationships; the formation of keratin; and the synthesis of intercollular materials. Radiobiological research dates back to 1921 , to the pioneer experiments on tissue cultures by Strangeways and Oakeley; radiation work was continued under the supervision first of Dr. F. G. Spear and then of the present deputy director, Dr. A. Glucksmann, who has extonded it to the clinico-pathological analysis of irradiated human tumours supplied by collaborating hospitals. Other cancer research comprises studies on human and animal leukæmia, and experiments on chemical carcinogenesis in vivo and in culture. In microbiology, work is being done on bacterial metabolism and fine structure, and on the host : parasite relationship between cells and pathogenic mycobacteria.

Looking back over our Laboratory's long and eventful career, I realize how extraordinarily fortunate the place has been in its friends. I think gratefully of that long line of disinterested people who have worked for it, given it money, and - on occasionstrenuously fought for it during tho past fifty years. It seemed fitting to dedicate the History to our first benefactor, E. Dorothy Strangeways, without whose courage and unselfishness the little Research Hospital of 1912 would not have lived to grow into the Strangeways Research Laboratory of 1962.

\title{
OBITUARIES
}

\section{Dr. Harry Wexler}

THE news of the sudden death of Dr. Harry Wexler, director of meteorological research in the U.S. Weather Bureau, at the early age of fifty-one came as a blow to his many friends in the world of international meteorology. He graduated in mathematics at Harvard University in 1932, followed by postgraduate work at the Massachusetts Institute of Technology which gained him the degree of Sc.D. in 1939. From 1940 until 1941 he was assistant professor of meteorology at the University of Chica.go, but most of his scientific life was spent in the U.S. Weather Bureau, in which he built up an impressive research division.

Wexler wrote profusely on atmospheric science, contributing noarly eighty papers dealing with such varied topics as the radiative cooling of the air, polar anticyclones, atmospheric turbidity, the structure of hurricanes and the study of the high atmosphere. Ho also published papers on glaciology and oceanography. Much of his work dealt with possible large-seale climatic effects of terrestrial and extraterrestrial events, such as the production of dust by volcanic eruptions and variations in the solar output, but recently he became absorbed in two major topics. One was the study of antarctic meteorology, especially as regards the consequences for global meteorology of the existence near the hub of atmospheric circulation in the Southern Hemisphere of "the world's most efficient cold air factory". During the International Geophysical Year he did much to organize meteorological observations at the South Pole, which he visited several times by aircraft. Afterwards, he turned his attention to the potentialities of weather satellites, in which he had an almost fanatical belief. His enthusiasm for this matter resulted in a long stay in Geneva earlier this year, where, with Prof. Bugaev of the U.S.S.R., he conducted an intensive and far-reaching survey, culmin- 
ating in the publication by the World Meteorological Organization of a lengthy report on the advancement of atmospheric sciences and their application in the light of developments in outer space. The essence of this report is a comprehensive scheme for a 'world weather watch' which, if constituted, might well revolutionize meteorology. Wexler was undoubtedly the driving force behind these ambitious proposals.

The lasting impression left by Wexler is that of an enthusiast whose cheerfulness, colourful speech and general friendliness remain as a cherished memory for his friends. In his own country his achievements were widely recognized. In 1945 he received the Robert M. Losey Award of the Institute of Aeronautical Sciences, in 1956 the U.S. Air Force Award for Exceptional Services, and his work for the International Geophysical Year and antarctic meteorology gained him the Department of Commerce Exceptional Service Medal and the U.S. Navy Public Service Award. He leaves a widow and two daughters.

Graham Sutton

\section{Dr. F. R. Irvine}

Dr. Frederick Robert Irvine, who died suddenly on August 20 in Ghana, at the age of sixty-four, was well known in West African agricultural and botanical circles. His long association, from 1924, with Achimota College in the Gold Coast and later with the University, at Legon, Ghana, earned him many African fiiends. He taught botany and agriculture at Achimota for sixteen years and his West African Botany (1931) met a great need as it was the first text-book on the subject.

Irvine was an assiduous collector and compiler of information on plants, especially as to their uses and vernacular names. His agricultural training at the then Armstrong College, the Newcastle Division of the University of Durham, naturally gave him a bias towards crops and food plants. His Plants of the
Gold Coast (1930) dealt principally with their uses, and in 1934 he published West African Agriculture which he was revising at the time of his death. However, he regretted that he was no taxonomist and this lack of a background in plant systematics was something of a handicap to him, especially during the compilation of his recent volume on the Woody Plants of Ghana (1961). He had recently accepted a research fellowship in Ghana to complete the companion volume on the herbs, but this remains unfinished. A further work, his Vocabularies of Plant Names in the Nigerian Languages, also remains unpublished.

His tall, slim, rather stooping figure was a familiar sight in the Kew Herbarium, where he would seek some obscure publication on food plants or ask advice on the taxonomy of the group in which he was then interested. Any further information was usually added to an already copiously annotated manuscript or inserted in a black pocket-book with the comment that he would now have to change half a dozen indexes. His interest in food plants ranged far and wide, especially those of the more primitive peoples such as the Australian Aborigines and the North American Indians. Besides his botanical activities, he also collected zoological information. Thus, he collaborated with J. R. Norman in The Fishes and Fisheries of the Gold Coast (1947).

He was keenly interested in the welfare of overseas students in the United Kingdom, and his work with the Society of Friends, notably as warden of their International Centre at Tavistock Square after the Second World War, brought him into contact with a large number of them.

While staying for a year in the United States, in 1959 , under Quaker auspices, he became seriously ill, but he made a remarkable recovery on his return to Britain, though he quickly aged and did not enjoy good health thereafter. He is survived by his wife, a son and two daughters. F. N. HEPPER

\section{NEWS and VIEWS}

Nobel Laureates in Medicine: Drs. F. H. C. Crick, F.R.S., M. H. F. Wilkins, F.R.S., and Prof. W. Watson

READERs of Nature will be pleased to learn of the award jointly of the Nobel Prize for Medicine to Dr. F. H. C. Crick, research worker for the Medical Research Council in the Council's Laboratory for Molecular Biology, Cambridge; Dr. M. H. F. Wilkins, deputy director of the Medical Research Council Biophysics Research Unit, Department of Biophysics, King's College, University of London; and Prof. James Watson, professor of biology in Harvard University, especially since the work of these three scientists has become well known through the columns of Nature and elsewhere. The official announcement cites the recipients for their achievement of a "most fundamental biological problem", the discovery of the molecular structure of deoxyribonucleic acid. The establishment of the 'biological code' especially for the formation of enzymes is now well known, and is exerting a profound influence on biochemical and biological research, especially in the fields of molecular biology and heredity. Recently, Dr. Crick was awarded the Gairdner Foundation Prize, and, among other awards, he was the first to receive the CharlesLéopold Mayer Prize of the Paris Academy of Sciences (Nature, 193, 223; 1962).

\section{History of Science and Technology at Imperial College: $\quad$ Prof. A. R. and Mrs. Hall}

Srmultaneodsly with the announcement by the University of London of the appointment of Prof. A. Rupert Hall to the chair of the history of science and technology in the Imperial College of Science and Technology, the College announces the appointment of Prof. Marie Boas Hall, his wife, to a senior lectureship in the same Department. Prof. Hall and his wife are at present professors of history and logic of science in the University of Indiana. They take up their new duties in the summer of 1963. The study of the history of science and technology in its own right presents both a challenge and an opportunity. The new Department will be headed by distinguished scholars who, both individually and in collaboration, have made an important contribution in this field. Unpublished Scientific Papers of Isaac Newton appeared under their joint authorship as did various articles on the man himself. Prof. Rupert Hall's 